\title{
A Review about Parenting Style and Parenting Practices and Their Consequences in Disabled and Non Disabled Children
}

\author{
Antonio Félix Raya ${ }^{1}$, Rosario Ruiz-Olivares ${ }^{1}$, María José Pino ${ }^{1} \&$ Javier Herruzo ${ }^{1}$ \\ ${ }^{1}$ Facultad de Ciencias de la Educación,Universidad de Córdoba, España, Spain \\ Correspondence: Antonio Félix Raya, University of Córdoba, San Alberto Magno S/N, Córdoba 14005, Spain. Tel: \\ 34-957-212-297. E-mail: antonio.raya@uco.es
}

Received: October 17, 2013

Accepted: November 13, 2013

Online Published: November 14, 2013

doi:10.5430/ijhe.v2n4p205

URL: http://dx.doi.org/10.5430/ijhe.v2n4p205

\begin{abstract}
In order to explain the worst levels of adaptation showed by children with disabilities in relation to non disabled children, this paper aims to carry out a review of the most important advances achieved in recent decades in the study of parenting styles and parenting practices in relation to academic competence and behavior problems of children with and without disabilities. For this, we have carried out an analysis of the main works that show this relationship in the population, and then, we did the same including disability as a differentiating factor. In this sense, the authoritative style and specific parenting practices such as setting limits, communication, autonomy or monitoring are described as good predictors of adaptive behavior in children. However, we miss studies to confirm this relationship in children with disabilities. In this population, most of the papers refer, on the one hand, to expectations and, on the other hand, the stress in parenting and its effect on the parents' mental health. In conclusion, the need to provide additional information about family relationships and disability is discussed.
\end{abstract}

Keywords: Parenting style, Parenting practices, Academic competence, Behavior problems, Disability

\section{Introduction}

There is no doubt that we are in the presence of one of the generations with higher grade of sensitivity towards infancy and this increases when the children have some disability. This high sensitivity contrasts with the problems that in many occasions, parents seem to have to obtain from their children an adaptable social behaviour which implies, among other things, an adequate academic development. A large number of studies during the last years have tried to shed light on the parenting style and other variables which intervene in the interaction parents and children. Althought not many of the analysts, take into account the disability condition as modulatory element. In this way, this paper pretends to review the main aspects which have been studied on the relation parents and children in a general way first, and bearing in mind the disability condition, later. We will start with the description of the phenomenon we are presenting.

Parenting style can be understood as a constellation of attitudes in the child, of which they are informed and, together, form an emotional environment in which parents' behaviours are exposed. These include the ones through which parents develop their own obligations as parents (parenting practices) as well as other kind of behaviours such as gestures, changes in the tone of voice, spontaneous expressions of affect, etcetera (Darling \& Steinberg, 1993).

The construct parenting style was initially developed as a global resource to describe the family context, up to the point that, in this context it was identified with itself. The analysis based on this conception seemed to be more predictive of the child' attributes than the ones based on the specific parental practices, because the influence of any particular practice in the child's development was easier lost among the complexity of other parenting attributes (Baldwin, 1948; Orlansky, 1949; Symonds, 1939).

For Baumrind, one of the pioneers in the study of the parenting style, socializing the child according to the demands of society but keeping a sense of personal integrity is the key element of the parenting role. Baumrind's model (1967, 1971), is different from previous researchers because she reflects a change in the concept about socialization, manifested in aspects such as the awareness that the child contributes with his or her own development through his or her influence on his or her parents. This made the author to define the parenting style as a characteristic of the relation parents-child more than a characteristic in parents.

Her first study was focused on the influence of the patterns of parenting authority in the first phases in the 
development of the child. In this way she began to articulate and widen the concept of parenting control which had been previously defined in many different ways such as uprightness, use of the physical punishment, or use of explanations, for example.

Based on the first Works carried out by Baumrind, parents, according to their educative style, were labelled in three groups: authoritative, authoritarian and permissive (Baumrind, 1971). In the early 80s, this tripartite model was firmly established in the field of the children's development. However, although Baumrind limited the field of her investigation to the influence of the variations in the parenting style among very well settled families, other researchers were interested in a wider range of families. The transformation of Baumrin's typologies which was developed by Maccoby and Martin (1983) facilitated the researches to generalize Baumrind's model to very different populations and this made them to create lineal constructs through which aspects, theoretically important of the parenting style, would be measured. Parenting style was defined then as a reflection of two underlying processes: the number and type of demands made by the parents (demandingness) and the contingency of the parenting reinforce (responsiveness). In that way, authoritative parents have high levels of affection and demand. Otherwise, authoritarian parents a high level of demand but a low level of affection. Anyhow, if empirically Baumrind found the permissive type, Maccoby and Martin distinguished two different subtypes in this parenting style: on the one hand, permissive parents, defined with a high level of affection but low level of demand and, on the other hand, negligent parents who are defined with a low level of both dimensions. The different types appear logically as a consequence of the mixture of both theoretical dimensions.

Many researches since Symonds (1939) have argued that parents' values and the aims through which they socialize their children are critical determiners of the parenting behaviours. These aims of socialization include searching the acquisition in children with specific abilities and behaviours such as appropriate attitudes, social abilities, academic ability, and etcetera. Although these aims and values have a direct effect on parenting behavior, the aims, only through these behaviours, can influence on the child development (Becker, 1964). Darling and Steinberg (1993) suggest that the parents' attributes influenced by these goals can be both parenting practices or parenting styles. Besides, they explain that to understand the processes through which parents influence in the development of their children, investigators should maintain this distinction between practice and style. For Darling and Steinberg (1993), parenting practices are behaviours defined with a specific content and some aims of socialization. Essentially, parenting practices are the mechanism with which parents help their children to respond towards their aims of socialization.

We can deduce from the cited works, that the study of the relations between parents and children, on the one hand, have been focused on the parenting styles as global aspect and, on the other hand, on the parenting practices and attitudes as more particular aspects with more direct influence in the daily interaction with children. For this reason, the relation between both types of variables with the academic competence and behavioural problems in children with and without disability is analyzed.

\section{Method}

For the collection, classification and revision of the mentioned works in this paper, we have used the main data bases currently existing in psychology and education. We have also used the wide list of e-magazines and magazines which are available for institutions such Cordoba University, through which we can access with the institutional licence.

Among the main data bases consulted, we can cite psycINFO, CSI-ISOC, ERIC, Medline, Psychology Journals, TESEO and SCOPUS.

The searching terms utiliced were, among others, parenting style, parenting practices, parenting and academic competence, parenting and behavior problems, parenting and disability, parenting and disability and academic competence, parenting and disability and behavior problems.

Once we revised and clasified all of them in relation to the treated topics of this paper, we extrated and organiced the main ideas we wanted to use in this manuscript.

\section{Results}

\subsection{Parenting style, parenting practices, and academic competence}

The relation between the school environment and the family has received much attention from some studies about socialization. Some of them have been focused on the particular practices which parents use to help their children for a better academic development; others have been focused on the adaptation of some parenting styles facing others to promote good academic results; and other studies have treated to merge both tendencies (Spera, 2005). 
Regarding to parenting practices, the most studied aspects according to Spera (2005) are:

-Parents implication: It involves activities such as having an interview with the tutor, helping the child with the homework, getting involved in the school body and participating in extracurricular activities. In this sense, studies such as Epstein and Sanders' (2002) or Gordon and Louis' (2009), have found a strong relation between parents implication and academic results.

-Homework supervision: It implies practices such as supervising the homework development, reviewing that they are finished, supervising activities with other schoolmates and asking about the progress in the school. Different studies have shown that homework supervision is related to a good elaboration and so, the academic success (Martínez Jr., DeGarmo \& Eddy, 2004; Muller \& Kerbow, 1993).

-Parents' aims, values and aspirations in regards to the child: Aims and aspirations are described as wished status or results that parents keep about their children and the influence on the behaviours towards them.

Values are referred to the importance of getting good academic results. Investigators such as Astone and McLanahan (1991) concluded that parents' aspirations, aims and values are related to children's aims, persistence in the school, enrolmentand attendance and, academic success. In a later study carried out by Spera, Wentzel and Matto (2009), the $85 \%$ of parents had high academic aspirations for their children (going to the University).

Other aspect to highlight is that the influence of the parents about their children's academic competence through their practices can also have an indirect influence through the teacher because, as García and Rosel (1999) point out, teachers tend to include the information they have about the family and the student, so that parents' implication as a way of connection between family and school has an essential role in the valuation that teachers have from a student.

In other ways, regarding to the investigations which have tried to relate parenting styles with their children's academic competence, one of the first studies about the topic compared an affective competence facing other restrictive one. In this work, Sears, Maccoby and Levin (1957) concluded that children exposed to disciplinary techniques based on affection, understood and embraced better their parents' aims and values.

Years later, Baumrind (1967) carried out a longitudinal study with a sample consisting of children from infancy to adolescence, and she found that, in preschool years, children whose parents were authoritative were maturer, independent, prosocial, active and had better academic results than children whose parents were not authoritative. However, children whose parents were permissive had lower score in self-confidence, self-control and competence. In adolescence, Baumrind (1989) confirmed that these characteristics were the same and the best academic results corresponded to children whose parents were authoritative.

Following the studies of Baumrind, Steinberg and their colleagues carried out some analyses with a large sample of adolescents. They found that parents who showed high levels of authoritative style providing affection, autonomy and demanded maturity, had children with better academic results (Steinberg, Elmen \& Mounts, 1989).

Recent studies continue supporting the idea that some parenting styles encourage the academic competence in children (Turner, Chandler \& Heffer, 2009). In this way, a study carried out by Aunola, Stattin and Nurmi (2000) in Finland, where they analysed the strategies of the academic success developed by children and its relation with their parents' educative style, found the following differences:

-Children with authoritative families applied the most adaptable strategies in academic situations. They had low level of expectancy in failure, passivity and not very efficient behaviours, showing a high level of self-confidence.

-Children whose parents were negligent showed the lowest adaptable strategies, with high levels of passivity, not very efficient behaviours and low self-confidence.

-Children with authoritarian families were more similar to the ones with negligent families according to the learning strategies.

-Surprisingly, children with permissive families were similar to the ones with authoritative families.

In Spain, both works carried out by Pelegrina, García and Casanova (2002) and Cerezo, Casanova, de la Torre and Carpio (2011) with the aim of relating the academic competence in adolescents with their parents' educative style, concluded that both the authotitative and permissive styles are related with:

-A better academic performance.

-A higher competence in the cognitive field.

-A higher intrinsic motivation. 
-A higher self-regulated use of the learning strategies.

A later work carried out by Saban, Herruzo and Raya (2013) concluded that the probability of getting less academic failure, would be the result of having education based on communication within the family, respect and affect, all those combined with little control and limits covering everything with humour and optimism.

In other ways, as a conclusion, it could be said that most of the authors coincide in pointing out that the authoritative style is related to the best academic results for three reasons ( ( Durkin, 1995):

-Authoritative parents provide their children a high level of emotional security.

-These parents also provide more explanations about how they behave.

-Finally, these parents keep a bidirectional communication with their children.

It seems to be very evident, bearing in mind the analyzed works, that there is a clear relation between the styles and parenting practices and those behaviours which lead to the academic success in children. Besides, we can deduce from this analysis that parents who choose an authoritative style are, at the same time, the ones who present more adequate parenting practices because their children obtain better academic results. This theory is repeated in the case of behaviour problems as it is described in the following section.

\subsection{Parenting style, parenting practices, and behaviour problems}

For Baumrind (1967), parents who presented an educative model based on the authoritarism and those who employed permissive and indulgent methods, tended to have more aggressive and impulsive children. According to this author, the higher frequency of hostile and aggressive behaviours in these children was originated because of the excessive punishment used by their authoritarian parents, or otherwise, in the lacking discipline imposed by their permissive and indulgent parents.

When Maccoby and Martin (1983) elaborated the model previously described, they proposed that an important factor of risk for the generalization in a pattern of an aggressive behavior in a child was the lack of affection in their parents towards him. As a result, he had an authoritarian style combining it with a high level of demand and a permissive style in the child when the level of demand was low.

Based on this model, recent studies such as Steinberg, Blatt-Eisengart and Cauffman's (2006) or Villar, Luengo, Gómez and Romero's (2003), where they related the dimensions which defined the four types of parents with four indicators of behavior problems, the following relation was established:

-The authoritative style is the best which prevents behaviour problems in children.

-The authoritarian style shows worse results than the authoritative one although they are better than the others.

-The negligent and the indulgent styles are those which present a more direct relation with the behavioral problems in children.

Regarding to the distinction made by Darling and Steinberg (1993), factorial analysis based on the parenting practices entails a series of constructs referred to the parents' behavior in the daily interaction with their children. One of the constructs nominated as limit setting, discipline, consistency or behavioral control, has been contemplated by numerous studies which coincide in pointing out that disciplinary patterns, reasonable and consistent, are related with less problems in children (Aunola \& Nurmi, 2005; Elgar, Waschbusch, Dadds \& Sigvaldasson, 2007; Knutson, DeGarmo \& Reid, 2004; McCoy, Frick, Money \& Ellis, 1999; Pfiffner, McBurnett, Rathouz \& Judice, 2005; Raya, Pino \& Herruzo, 2011; Tur, Mestre \& Del Barrio, 2004). One of the main requirements to establish consistent disciplinary pattern is the existence of an adequate relation between parents and children. In this line, numerous investigators relate externalizing behaviour problems with aspects such as bad communication (Krinsley \& Bry, 1992; Villar et al., 2003) or lack of implication and compromise with the children's upbringing. (Finkenauer, Engels \& Baumeister, 2005; Kimonis et al., 2006; McCoy et al., 1999).

Other frequent aspect studied is the autonomy degree. According to works from Bynum and Kotchick (2006), Reitz, Dekovic and Meijer (2006) or Tur et al. (2004), responsibility is promoted and it is related with less problems in the child. In spite of that, other works from Beyers, Bates, Pettit and Dodge (2003) or Vazsonyi (2004), for instance, concluded that a high degree of autonomy and lack of supervision could be identified with a negligent attitude in parents which could produce a risk situation.

In other ways, there are other variables which reflect the degree of support perceived in the upbringing and which have been related to the externalizing behabiour problems as the long-term poverty (Pachter, Auinger, Palmer \& Weitzman, 2006) or the unemployment (Knutson et al., 2004). Bad quality of social networks has been also pointed 
out as a source of stress and dissatisfaction in upbringing (Vandewater \& Lansford, 2005).

Studies carried out with Spanish population have shown that variables such as autonomy, the support received or discipline are very related with certain behaviour problems in children as hyperactivity and impulsiveness (Raya, Herruzo \& Pino, 2008) or aggressive behavior (Raya, Pino \& Herruzo, 2009; Samper, Aparici \& Mestre, 2006). It could be also maintained that not very authoritative parents, who are not very communicative or consistent in rules fulfillment and they do not receive support enough in parenting practices, are important predictors of the possible risk of having the behavior problems previously mentioned. If any type of disability in children is also added, the consequences for the family well-being can be quite negative as it has been described in most of the cited works in the following section.

\subsection{Parenting style, parenting practices, and disability}

The growing social sensitivity towards the full inclusion and normalization in people with disability is surprising because, the school failure range presented among this collective, is higher than the population with disability. For this reason, the Inquiry of Disability, Personal Autonomy and Dependency situations (EDAD, 2008) of the Instituto Nacional de Estadistica (INE) shows that the illiteracy range in disabled people aged between 25 and 44 is $8.6 \%$ facing $0.9 \%$ in the rest of the general population; the $37.4 \%$ of these people has studied courses over the obligatory ones, facing the $60,4 \%$ of the general population; only the $10,5 \%$ has finished superior studies facing the $24.1 \%$ of the general population who has concluded the same level of studies. Other previous surveys carried out in the same Institute, such as Encuesta sobre Discapacidades, Deficiencias y Estado de Salud (EDDES, 1999), reflected that the percentage of people with finished university studies was four times fewer in the case of people with disability (3.6\%) than in population without disability (12.7\%). This data is comparable to the one offered by North American people in the $90 \mathrm{~s}$, where the $54 \%$ of the secondary students without disability acceded to the University, facing the $12 \%$ of the students with disability who acceded (Faiweather \& Shaver, 1990). Therefore, within this collective is much more urgent the necessity of adequate educative patterns which help them to face the problems previously mentioned (Meadow-Orleans, 2002). The lack of existent references about parenting practices in parents with disabled children, show that the family supports in the promotion and maintenance of encouragement for the school success is essential to make the children stay for long in school and the advance in the different levels of education. The key to make the disabled child be a successful adult can be the good family guidance (Barraga, 1991). For this reason, expectations which parents present of their children's academic success is a very interesting factor in the study of the family relations in children with disability. In some ways, these expectations affect the academic efficiency and the behavioural attachment in the child and, at the same time, it has a feedback in the results obtained by him (Masino \& Hodapp, 1996). An example of the obvious mistake which many parents make in relation to this aspect is what was resulted in a study carried out by Leonard in 1986 (cited in Sanchez-Escobedo, 2006), where children with visual impairment who presented passivity and low esteem were related with unfortunate comparisons in parents who contributed to increase anxiety in relation to the child's development.

If permissive and over-protective parents who do not allow the child to participate in any activity with his schoolmates is added to the previous idea, a family situation without stimulation can be generated and the opportunities for the full development decrease making the child be more dependent (Mercer, 1991).

For this reason, one of the main characteristics in parents of children with disabilities is the excessive over-protection, hindering with this that the child incorporates the decision-making and the coexistence with other people. In fact, many of the fears and passive attitude of the disabled adult were promoted and learnt within his family (Sanchez-Escobedo, 2006).

Following the same line of the previous two authors, in a current study carried out in Spain by Raya, Ruiz-Olivares, Pino and Herruzo (2013) concluded that the least provided autonomy from the parents and a higher relaxation in the limits setting in children, were the main aspects to distinghish between families with children with physical and sensorial disabibities and their peers without disabilities.

But the imbalance in children with disabilities in relation to the characteristics of his family environment is not limited to the academic success only but it is also manifested in both externalizing and internalizing behaviour problems. In this sense, Baumrind's theory $(1967,1971)$ which explains that the relation between parenting style and children behavior is reciprocal and bidirectional is especially relevant when we talk about variables such as parenting stress or the support received in parenting practices (Margalit \& Anconina, 1991; Jackson, Traub \& Turnbull, 2008). In fact, it seems to be that parents with disabled children have higher levels of stress and lower levels of support received, which can be related at the same time, with behavior problems and socio-emotional problems in their children (Hastings, 2002; Hintermair, 2006). 
One of the questions that have been often related with stress perceived in the family environment is the lack of communication or even its bad quality. Although, as we pointed out before, the use of the inadequate communicative strategies in the family environment is related with behavior problems in children, this situation is even worse when there is a disability affecting them directly, as it occurs in children with hearing impairment (Barker, Quittner, Fink, Eisenberg, Tobey \& Niparko, 2009; Van Eldik, Treffers, Veerman \& Verhulst, 2004).

This lack of support received and the problems for communicating with children give as a result a series of negative feelings such as dissatisfaction (Bellin, Bentley \& Sawin, 2009), frustration or incompetence (Koester \& Meadow-Orleans, 1999; Kushalnagar, Krull, Hannay, Mehta, Caudle \& Oghalay, 2007) which, at the same time, are related to behavioural imbalances in children.

In spite of that, other variables frequently studied in general population such as the limits setting or the implication in parenting practices, have not been addressed. Their influence on the academic competence and behavior problems, have been a recurrent object of study as we could see in previous sections. Even though there are no conclusive data, the lack of works done confirms that having a disabled child is a source of stress added in the family relations which difficult, in many cases, the development of certain parenting practices. It also empowers negative effects on $n$ an inadequate style and practices. For this reason the support that these families need to receive is a decisive factor.

\section{Discussion}

In spite of that, the study of parenting style and practices goes back to the first half of the last century and, in the last decades, they have been quite prolific in relation to the advances in this field of study in psychology and education, the constant change in lifestyles is together with changes in the way of educating children and understanding family relationships. This change can be considered even higher in the case of children with disability, where these changes come together with a change in sensitivity towards people with disabilities, result of the development of normalization in advanced societies. But, to make this process of normalization be a reality, is important that the people affected by these problems begin to treat disabled people with normality, that is to say, avoiding attitudes which are easily observable in parents such as the excess of control or overprotection.

Recent studies referred in this job have shed light on the validity of Baumrind's model (1967) as a classification system of interaction style between parents and children, being the authoritative style the most accepted as a predictor of good results in academic level and in adaptation level ( p.e. Aunola et al., 2000; Steinberg et al., 2006; Turner et al., 2009; Villar et al., 2003). In spite of that, the relevance obtained for these attitudes and expectations can be considered as one more step in the study of these complex relations and, above all, parenting practices which permit to speak about behaviours and particular performances which are behind many of the problems that are currently presented in children in both the school and family environments (p.e. Aunola \& Nurmi, 2005; Gordon \& Louis, 2009; Knutson et al., 2004; Martínez Jr. et al., 2004; McCoy et al., 1999).

However, we cannot maintain the same when we add the variable of disability as a differentiating factor. The studies which reflect the influence of particular circumstances in family relations are lacking, being limited only to the study of some variables such as communication (above all with children with hearing impairment) (e.g. Barker et al., 2009; Van Eldik et al., 2004), parenting stress (e.g. Hastings, 2002; Hintermair, 2006) or the effects on parents' mental health (e.g. Bellin et al., 2009; Koester \& Meadow-Orleans, 1999; Kushalnagar et al., 2007), without noticing those differentiating elements of the relations between parents and disabled children, what give as a result worse levels of adaptation which questions normalization and the complete integration of children with disability.

In this way, it is difficult to conclude clearly about the relation between the educative style and the academic competence or the bahaviour problems in disabled children, because we would need wider comparative studies to shed some light on a fact which is validated which is, for instance, the worst results that obtain the disabled population in relation with the academic results and the final eucative level that they reach.

Something that seems to be evident, in disabled children and in non disabled ones, is that interation with their parents and their educative style can be decisive in their academic performance and in their adaptation to the closest envirnment.

\section{Acknowledgements}

This work has been partly funded by the Ministry of Science and Innovation (Spain).

\section{References}

Astone, N.M. \& McLanahan, S.S. (1991). Family Structure, parental practices and high school completion. American Sociological Review, 56, 309-320. http://dx.doi.org/10.2307/2096106 
Aunola, K. \& Nurmi, J.E. (2005). The Role of Parenting Styles in Children's Problem Behavior. Child Development, 76, 1144-1159. http://dx.doi.org/10.1111/j.1467-8624.2005.00840.x-i1

Aunola, K., Stattin, H. \& Nurmi, J.E. (2000). Parenting styles and adolescent's achievement strategies. Journal of Adolescence, 23, 205-222. http://dx.doi.org/10.1006/jado.2000.0308

Baldwin, A.L. (1948). Socialization and the parent-child relationship. Child Development, 19, 127-136. http://dx.doi.org/10.2307/1125710

Barker, D.H., Quittner, A.L., Fink, N.E., Eisenberg, L.S. Tobey, E.A. \& Niparko, J.K. (2009). Predicting behavior problems in deaf and hearing children: The influences of language, attention, and parent-child communication. Development and Psychopathology, 21 (2), 373-392. http://dx.doi.org/10.1017/S0954579409000212

Barraga, N. (1991). Discapacidad visual y aprendizaje. Región Latinoamericana, 77.

Baumrind, D. (1967). Child care practices anteceding three patterns of preschool behaviour. Genetic Psychology Monographs, 75, 43-88.

Baumrind, D. (1971). Current patterns of parental authority. Developmental Psychology Monograpf, 4 (1, Pt. 2). http://dx.doi.org/10.1037/h0030372

Baumrind, D. (1989). Rearing competent children. En W. Damon (Ed.), Child development today and tomorrow (pp. 349-378). San Francisco: Jossey-Bass.

Becker, W.C. (1964). Consequences of different kinds of parental discipline. En M. L. Hoffman y L. W. Hoffman (Eds.), Review of child development research (Vol. 1, pp. 169-208). New York: Russel Sage Foundation.

Bellin, M.H. Bentley, K.J. \& Sawin, K.J. (2009). Factors Associated With the Psychological and Behavioral Adjustment of Siblings of Youths With Spina Bifida. Families, Systems \& Health. 27 (1), 1-15. http://dx.doi.org/10.1037/a0014859

Beyers, J.M., Bates, J.E., Pettit, G.S. \& Dodge, K.A. (2003). Neighbourhood Structure, Parenting Processes, and the Development of Youths' Externalizing Behaviors: A Multievel Analysis. American Journal of Community Psychology, 31, 35-53. http://dx.doi.org/10.1023/A:1023018502759

Bynum, M.S. \& Kotchick, B.A. (2006). Mother-Adolescent Relationship Quality and Autonomy as Predictors of Psychosocial Adjustment Among African American Adolescents. Journal of Child and Family Studies, 15, 529-542. http://dx.doi.org/10.1007/s10826-006-9035-z

Cerezo, M.T., Casanova, P.F., de la Torre, M.J. \& Carpio, M.V. (2011). Estilos educativos paternos y estrategias de aprendizaje en alumnos de Educación Secundaria. European Journal of Education and Psychology, 4 (1), 51-61.

Darling, N. \& Steinberg, L. (1993). Parenting Style as Context: An Integrative Model. Psychological Bulletin, 113 (3), 487-496. http://dx.doi.org/10.1037/0033-2909.113.3.487

Durking, K. (1995). Developmental Social Psychology: From Infance to Old Age. Malden, MA: Blackwell.

Elgar, F.J., Waschbusch, D.A., Dadds, M.R. \& Sigvaldasson, N. (2007). Development and Validation of a Short Form of the Alabama Parenting Questionnaire. Journal of Child and Family Studies, 16, 243-259. $\mathrm{http}: / / \mathrm{dx}$.doi.org/10.1007/s10826-006-9082-5

Fairweather, J.S. \& Shaver, D.M. (1990). A troubled future?: Participation in postsecondary education by youth with disabilities. The Journal of Higher Education, 61, (3), 332-348. http://dx.doi.org/10.2307/1982134

Finkenauer, C., Engels, R.C. \& Baumeister, R.F. (2005). Parenting behaviour and adolescent behavioural and emotional problems: The role of self-control. International Journal of Behavioral Development, 29, 58-69. http://dx.doi.org/10.1080/01650250444000333

García, F.J. \& Rosel, J. (1999). Características familiares y estimación de los resultados educativos de los alumnos por el profesor. Psicothema, 11 (3), 587-600.

Gordon, M.F. \& Louis, K.S. (2009). Linking Parent and Community Involvement with Student Achievement: Comparing Principal and Teacher Perceptions of Stakeholder Influence. American Journal of Education, 116 (1), 1-31. http://dx.doi.org/10.1086/605098

Hastings, R.P. (2002). Parental stress and behaviour problems of children with developmental disability. Journal of Intellectual \& Developmental Disability, 27 (3), 149-160. http://dx.doi.org/10.1080/1366825021000008657

Hintermair, M. (2006). Parental Resources, Parental Stress, and Socioemotional Development of Heard and Hard of Hearing Children. Journal of Deaf Studies and Deaf Education, 11 (4), 493-513. 
http://dx.doi.org/10.1093/deafed/en1005

Instituto Nacional de Estadística (1999). Encuesta sobre Discapacidades, Deficiencias y Estado de Salud (EDDES). Retrieved from www.ine.es

Instituto Nacional de Estadística (2008). Encuesta de Discapacidad, Autonomía Personal y Situaciones de Dependencia (EDAD). Retrieved from www.ine.es

Jackson, C.W., Traub, R.J. \& Turnbull, A.P. (2008). Parent's Experiences With Childhood Deafness: Implications for Family-Centered Services. Comunication Disorders Quarterly, $29 \quad$ (2), 82-98. http://dx.doi.org/10.1177/1525740108314865

Kimonis, E.R., Frick, P.J., Boris, N.W., Smyke, A.T., Cornell, A.H., Farrell, J.M. \& Zeanah, C.H. (2006). Callous-unemotional features, behavioral inhibition, and parenting: independent predictors of aggression in a high-risk preschool sample. Journal of Child and Family Studies, 15, 745-756. http://dx.doi.org/10.1007/s10826-006-9047-8

Knutson, J.F., DeGarmo, D.S. \& Reid, J.B. (2004). Social Disadvantage and Neglectful Parenting as Precursors to the Development of Antisocial and Aggressive Child Behavior: Testing a Theoretical Model. Aggressive Behavior, 30, 187-205. http://dx.doi.org/10.1002/ab.20016

Koester, L.S. \& Meadow-Orleans, K.P. (1999). Responses to interactive stress: Infants who are deaf or hearing. American Annals of the Deaf, 144 (5), 395-403. http://dx.doi.org/10.1353/aad.2012.0185

Krinsley, K.E. \& Bry, B.H. (1992). Sequential analyses of adolescent, mother and father behaviors in distressed and non distressed families. Child \& Family Behavior Therapy, 13, 45-62. http://dx.doi.org/10.1300/J019v13n04_03

Kushalnagar, P., Krull, K., Hannay, J., Mehta, P., Caudle, S. \& Oghalay, J. (2007). Intelligence, parental depression, and behavior adaptability in deaf children being considered for cochlear implantation. Journal of Deaf Studies and Deaf Education, 12 (3), 335-349. http://dx.doi.org/10.1093/deafed\%2Fenm006

Maccoby, E.E. \& Martin, J.A. (1983). Socialization in the context of the family: Parent-child interaction. En P. H. Mussen \& E. M. Hetherington (Eds.), Handbook of child psychology: Vol. 4. Socialization, personality and social development ( $4^{\mathrm{a}}$ ed., pp. 1-101). New York: Wiley.

Margalit, M. \& Ankonina, D.B. (1991). Positive and negative affect in parenting disabled children. Counselling Psychology Quarterly, 4 (4), 289-299. http://dx.doi.org/10.1080/09515079108254437

Martínez Jr., C.R., DeGarmo, D.S. \& Eddy, J.M. (2004). Promoting academic success among Latino youth. Hispanic Journal of Behavioral Sciences, 26 (2), 128-151. http://dx.doi.org/10.1177/0739986304264573

Masino, L.L. \& Hodapp, R.M. (1996). Parental education expectations for adolescents with disabilities. Exceptional children, 62 (6), 515-534.

McCoy, M.G. Frick, P.J., Loney, B.R. \& Ellis, M.L. (1999). The Potential Mediating Role of Parenting Practices in the Development of Conduct Problems in a Clinic-Referred Sample. Journal of Child and Family Studies, 8, 477-494. http://dx.doi.org/10.1023/A:1021907905277

Meadow-Orleans, K.P. (2002) Parenting with a sensory or physical disability. En M.H. Bornstein (ed) The handbook of parenting. Vol IV. 259-293. Mahwah, N.J.: Lawrence-Earlbaum Ass Publisher.

Mercer, C. (1991). Dificultades de aprendizaje 1. CEAC (Ed), Perú.

Muller, C. \& Kerbow, D. (1993). Parent involvement in the home, school and community. En B. Schneider y J. S. Coleman (Eds.), Parents, Their Childrens, and Schools (pp. 13-39). Boulder, CO: Westview.

Orlansky, H. (1949). Infant care and personality. Psychological Bulletin, 46, 1-48. http://dx.doi.org/10.1037/h0058106

Pachter, L.M., Auinger, P., Palmer, R. \& Weitzman, M. (2006). Do Parenting and the Home Environment, Maternal Depresion, Neighbourhood, and Chronic Poverty Affect Child Behavioral Problems Differently in Different Racial-Ethnic Groups? Pediatrics, 117, 1329-1338. http://dx.doi.org/10.1542/peds.2005-1784

Pelegrina, S., García, M.C. \& Casanova, P.F. (2002). Los estilos educativos de los padres y la competencia académica de los adolescentes. Infancia y Aprendizaje, 25 (2), 147-168. http://dx.doi.org/10.1174/021037002317417796

Pfiffner, L.J., McBurnett, K., Rathouz, P.J. \& Judice S. (2005). Family Correlates of Oppositional and Conduct Disorders in Children With Attention Deficit/Hyperactivity Disorder. Journal of Abnormal Child 
Psychology, 33, 551-563. http://dx.doi.org/10.1007/s10802-005-6737-4

Raya, A.F., Herruzo, J. \& Pino, M.J. (2008). El estilo de crianza parental y su relación con la hiperactividad. Psicothema, 20, 691-696.

Raya, A.F., Pino, M.J. \& Herruzo, J. (2009). La agresividad en la infancia: el estilo de crianza parental como factor relacionado. European Journal of Education and Psychology, 2, 211-222.

Raya, A.F., Pino, M.J. \& Herruzo, J. (2011). Family variables related to behavioral problems in childhood. Israel Journal of Psychiatry, 48, 117-122.

Raya, A.F., Ruiz-Olivares, R. Pino, M.J. \& Herruzo, J. (2013, october). Diferencias entre las prácticas de crianza de los padres y madres de niñas y niños con y sin discapacidad. Paper presented at the I Congreso Internacional de Ciencias de la Educación y del Desarrollo. Santander, Spain.

Reitz, E., Dekovic, M. \& Meijer, A.M. (2006). Relations between parenting and externalizing and internalizing problem behaviour in early adolescence: Child behaviour as moderator and predictor. Journal of Adolescence, 29, 419-436. http://dx.doi.org/10.1016/j.adolescence.2005.08.003

Saban, S., Herruzo, J. \& Raya, A.F. (2013). Relación entre estilos educativos familiares y la inclusión en Programas Diversificación Curricular: un elemento a considerar para la mejora de la convivencia escolar. Apuntes de Psicología, 31 (2), 11-13

Samper, P., Aparici, G. \& Mestre, V. (2006). La agresividad auto y heteroevaluada: variables implicadas. Acción Psicológica, 2, 155-168. http://dx.doi.org/10.5944/ap.4.2.484

Sánchez Escobedo, P. (2006). Discapacidad, familia y logro escolar. Revista Iberoamericana de Educación, 40 (2), $1-10$.

Sears, R.R., Maccoby, E. \& Levin, H. (1957). Patterns of child rearing. Evanston IL: Row, Peterson.

Spera, C. (2005). A Review of the Relationship Among Parenting Practices, Parenting Styles, and Adolescent School Achievement. Educational Psychology Review, 17 (2), 125-146. http://dx.doi.org/10.1007/s10648-005-3950-1

Spera, C., Wentzel, K.R. \& Matto, H.C. (2009). Parental Aspirations for Their Children's Educational Attainment: Relations to Ethnicity, Parental Education, Children's Academic Performance, and Parental Perceptions of School Climate. Journal of Youth and Adolescence, 38 (8), 1140-1152. http://dx.doi.org/10.1007/s10964-008-9314-7

Steinberg, L., Blatt-Eisengart, I. \& Cauffman, E. (2006). Patterns of Competence and Adjustment Among Adolescents from Authoritative, Authoritarian, Indulgent and Neglectful Homes: A Replication in a Sample of Serious Juvenile Offenders. Journal of Research on Adolescence, 16 (1), 47-58. http://dx.doi.org/10.1111/j.1532-7795.2006.00119.x

Steinberg, L., Elmen, J.D. \& Mounts, N.S. (1989). Authoritative parenting, psychosocial madurity and academic success among adolescents. Child Development, 60, 1424-1436. http://dx.doi.org/10.2307/1130932

Symonds, P.M. (1939). The psychology of parent-child relationships. New York: Appleton-Century-Crofts.

Tur, A., Mestre, V. \& Del Barrio, M.V. (2004). Los problemas de conducta exteriorizados e interiorizados en la adolescencia: relaciones con los hábitos de crianza y con el temperamento. Acción Psicológica, 36, 207-221. http://dx.doi.org/10.5944/ap.3.3.514

Turner, E.A., Chandler, M. \& Heffer, R.W. (2009). The Influence of Parenting Styles, Achievement Motivation, and Self-Efficacy on Academic Performance in College Students. Journal of College Student Development, 50 (3), 337-346. http://dx.doi.org/10.1353/csd.0.0073

Van Eldik, T., Treffers, P.D.A., Veerman, J.W. \& Verhulst, F.C. (2004). Mental Health Problems of Deaf Dutch Children As Indicated by Parents' Responses to the Child Behavior Checklist. American Annals of the Deaf, 148 (5), 390-395. http://dx.doi.org/10.1353/aad.2004.0002

Vandewater, E.A. \& Lansford, J.E. (2005). A Family Process Model of Problem Behaviors in Adolescents. Journal of Marriage and Family, 67 (febrero) 100-109. http://dx.doi.org/10.1111/j.0022-2445.2005.00008.x

Vazsonyi, A.T. (2004). Parent-Adolescent Relations and Problem Behaviors: Hungary, the Netherlands, Switzerland, and the United States. Marriage and Family Review, 35, 161-187. http://dx.doi.org/10.1300/J002v35n03_09

Villar, P., Luengo, M.A., Gómez, J.A. \& Romero, E. (2003). Una propuesta de evaluación de variables familiares en la prevención de la conducta problema en la adolescencia. Psicothema, 15 (4), 581-588. 